\section{En kritisk analyse av evidensbevegelsen}

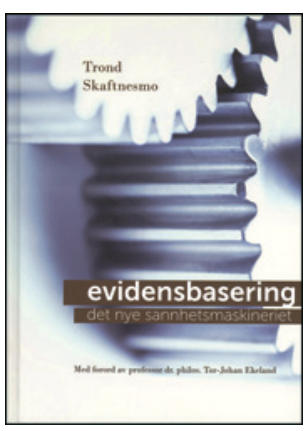

Trond Skaftnesmo

Evidensbasering

Det nye sannhetsmaskineriet. $198 \mathrm{~s}, \mathrm{tab}$,

ill. Stavanger: Paradigmeskifte Forlag, 2013.

Pris NOK 285

ISBN 978-82-93238-08-8

«Evidens» er et av vår tids honnørbegreper. Klinisk praksis bør «evidensbaseres» - det samme kreves i økende grad for virksomheten innen andre samfunnssektorer, som utdanning og politikk. Motforestillinger blir lett parkert - for hvem kan egentlig være mot kunnskap?

Denne boken bringer en sårt tiltrengt kritisk analyse av evidensbevegelsen, blant annet ved å påvise dens normative karakter. For det er ikke snakk om et verdinøytralt, kontekstfritt eller objektivt fenomen, men nettopp en «bevegelse» med vitenskapshistoriske, sosiologiske og ideologiske røtter. Forfatteren gir en grundig fremstilling av slektskapet mellom evidensbevegelsen og det positivistiske vitenskapssynet. Videre analyseres sammenhengen med bestemte former for politikk og maktutøvelse: «Kunnskapsproduksjonen» (merk industrispråket!) innenfor evidensbevegelsen gir opphav til veiledere og retningslinjer, som i sin tur danner grunnlag for byråkratiske og juridiske kontrollsystemer. Skaftnesmo påviser en forbindelse til New public management og hevder at «evidensbevegelsen er en del av en større kulturstrøm [...] en mektig impuls i retning av Teknopolis: et samfunn som setter det teknologidrevne systemet foran subjektet.» Han er særlig bekymret for denne utviklingen innenfor skolesektoren, fordi den profesjonelle yrkesutøver undermineres: God undervisning kan ikke alene sikres gjennom evidensbaserte retningslinjer for pedagogisk virksomhet, men forutsetter også en inspirert, erfaren og profesjonell laerer. Tilsvarende gjelder for helsevesenet: God pasientbehandling handler om mer enn å slå opp i de siste «guidelines» - det kreves også noe så gammeldags og subjektivt som klinisk skjønn.

Bokens fremste styrke er det brede perspektivet, der leseren presenteres for grundige filosofiske, historiske og sosiologiske analyser. Videre unngår forfatteren å havne i motsatt ekstremposisjon han er nøye med å fremheve hvordan evidensbevegelsens mål og metode har avgjørende betydning for vitenskapelig innsikt og profesjonell praksis. Skaftnesmos anliggende er ikke å lansere et alternativ, men å «gjøre verden hel igjen» slik at ulike vitenskapelige metoder og profesjonell erfaring ikke ses som konkurrerende kilder til innsikt, men kan supplere hverandre.

Bokens svakhet er en litt uoversiktlig disposisjon kombinert med en viss ordrikdom. Den hadde tjent på strammere redigering. Den anbefales like fullt varmt til alle som er opptatt av grunnleggende utviklingstrekk i vårt eget fag - og i samfunnet for øvrig.

\section{En milepel for religionspsykologifaget}

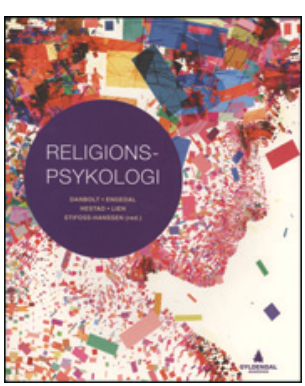

Lars Johan Danbolt, Leif Gunnar Engedal, Hans Stifoss-Hanssen et al, red. Religionspsykologi

397 s, tab, ill. Oslo: Gyldendal Akademisk, 2014. Pris NOK 489

ISBN 978-82-05-41634-5

Da psykologi ble etablert som fag for vel hundre år siden, var religion og religiøse erfaringer en naturlig del av fagfeltet. Interessen for religion kom etter hvert i skyggen av studier av drifter, atferd, emosjoner og kognisjon. De siste tiårene har imidlertid mengden av religionspsykologiske forskningsrapporter økt betydelig. Religionspsykologien studerer hvordan religionen motiverer og påvirker menneskers tenkning, atferd og verdisyn. Det norske fagmiljøet er tverrfaglig og har to kliniske tyngdepunkter, Modum Bad og Religionspsykologisk forskningssenter ved Sykehuset Innlandet HF.

Ved denne bokutgivelsen viser det norske fagmiljøet både bredde og kompetanse. Den fremstår som en lærebok som belyser en rekke sentrale områder av religionspsykologien. Den har i alt 26 bidragsytere hvorav 23 er norske. Stoffet presenteres i 28 kapitler som spenner fra historiske linjer til dagsaktuelle problemstillinger, fra identitetsdannelse til religiøse sekter, og fra tro og psykoser til religion og helse. Boken tar også opp tidsaktuelle temaer, som hvordan religion kan motivere til både gode og onde handlinger, om tro kan forebygge sykdom, og om det kan påvises sammenheng mellom prosesser $\mathrm{i}$ hjernen og åndelige erfaringer.

Jeg vil fremheve kapitlet om religiøs mestring som særlig relevant for helsevesenet. Mestringsevnen settes på prøve når mennesker lider fysisk eller psykisk. Særlig når livstruende eller kroniske lidelser rammer, er mestringsevnen avgjørende for hvordan pasienten klarer å bære sin lidelse. Likevel blir dette i liten grad tematisert og kommunisert i møte mellom helsearbeider og pasient. Noe av forklaringen kan være at religiøsitet nesten ikke er nevnt i den gjengse litteraturen om psykologisk mestring.

Utgivelsen er velredigert og vil bli stående som et norsk standardverk innen faget. Den kan leses med utbytte av alle med interesse for troens betydning for enkeltmennesker og samfunn.

Stig Heskestad

Sjeflege, Jæren distriktpsykiatriske senter 